\title{
Does Exchange Rate Volatility Affect Economic Growth in Nigeria?
}

\author{
Tule Kpughur Moses ${ }^{1}$, Oboh Ugbem Victor ${ }^{1}$, Ebuh Godday Uwawunkonye ${ }^{1}$, \\ Onipede Samuel Fumilade ${ }^{1} \&$ Gbadebo Nathaniel $^{1}$ \\ ${ }^{1}$ Monetary Policy Department, Central Bank of Nigeria, Nigeria \\ Correspondence: Ebuh Godday Uwawunkonye, Monetary Policy Department, Central Bank of Nigeria, No 33 \\ Tafawa Balewa Way, Central Business District, P.M.B. 0187, Garki, Abuja, Nigeria. E-mail: guebuh@cbn.gov.ng
}

Received: March 28, 2020

doi:10.5539/ijef.v12n7p54
Accepted: June 4, 2020

Online Published: June 22, 2020

URL: https://doi.org/10.5539/ijef.v12n7p54

\begin{abstract}
This study used monthly data from 2003 to 2017 to analyze the effects of USD/NGN exchange-rate volatility on Nigeria's economic growth. The results from generalized autoregressive conditional heteroscedasticity (GARCH) and vector error correction model (VECM) analyses indicated that USD/NGN volatility had a significant effect on the country's gross domestic product (GDP) growth. The results of the Granger causality/block exogeneity Wald tests and impulse-response functions also indicated that USD/NG volatility had a significant negative effect on the country's GDP growth. Moreover, USD/NGN exchange-rate volatility was found to exhibit short-term unidirectional causality for economic growth. However, a bidirectional relationship was confirmed between narrow money supply and economic growth. Yet, it was also found that the interbank exchange rate, which is a semiofficial Forex window, had little effect on Nigeria's economic growth - a strong indication that a large portion of the productive sector lacks access to this Forex platform.
\end{abstract}

Keywords: economic growth, exchange-rate volatility, money supply, vector error correction

JEL Codes: E41, F31, F41, F47.

\section{Introduction}

The collapse of the Bretton Woods system in the early 1970s and the subsequent adoption of free-market principles to determine exchange rates for most countries has attracted attention from academics and policy makers, especially regarding the possible effects of exchange-rate volatility on economic growth. Such investigations are likely to continue given the current era of increasing globalization, financial deregulation, and economic crisis (Katsiime et al., 2015). Exchange-rate fluctuations continue to cause concern among national governments because of the increasing linkage between citizens' economic welfare and a country's level of global competitiveness. Minimizing exchange-rate volatility is particularly relevant for developing economies with fragile financial systems and high vulnerability to external shocks (Aghion et al., 2009).

Nearly five decades after the collapse of the Bretton Woods systems, opinions continue to differ about the merits of fixed versus floating exchange rates. On one hand, critics of flexible exchange rates have argued that their volatility increases trade uncertainty, reduces trade volume, and exposes importers to undue risks. Some studies have even found positive effects for hard exchange pegs, especially in promoting trade openness and economic integration (Frankel \& Rose, 2002). On the other hand, proponents of flexible exchange rates have suggested that they enhance fiscal discipline, since unsound fiscal policies under a given regime could easily manifest through fluctuations in exchange rates and price levels (Rose, 2000).

Exchange-rate volatility affects several macroeconomic variables, such as exports, employment growth, inflation, investment, and overall economic growth (Alagidede \& Ibrahim, 2016). While the adverse effects of exchange-rate fluctuations are obvious, their implications for economic growth are rarely discussed. In line with orthodox economic theory, an exchange-rate devaluation may affect the economy in two major ways. First, it could prompt an expenditure switch in which domestic consumers show less demand for imported goods and services in favor of locally produced import-substituting goods. Second, by lowering export prices, devaluation enhances international competitiveness and exports. However, depreciation through the supply-side channel could increase the costs of intermediate goods used for production in developing economies. This is especially critical for developing countries characterized by the nonavailability of local substitutes for imported inputs (see VanWijnbergen, 1989). 
Although there is an ample body of empirical research on the effect of exchange-rate volatility on economic growth in Nigeria, there is a lack of consensus regarding the direction and extent of the effect. Similarly, while nominal devaluation has recently attracted a lot of attention, much of the research has focused on the transmission to inflationary pressures, with little reference to its effect on economic growth. This study, therefore, aimed to empirically investigate the effects of exchange-rate volatility on Nigeria's economic growth. Understanding such effects is critical for informing policy that aims to ensure the stability of the country's currency.

The rest of this study is organized as follows: The next section presents some stylized facts about exchange-rate volatility in Nigeria, while section 3 reviews the relevant literature. In section 4, we present the methodology, while section 5 presents and discusses the empirical findings. Section 6 provides the conclusion and policy recommendations.

\section{Stylized Facts about the Naira Exchange Rate}

Exchange-rate volatility and its effect on macroeconomic development continue to attract interest from various stakeholders, including policy makers, researchers, and development practitioners, especially in developing and import-dependent economies, such as Nigeria. In such contexts, policy makers adopt various regimes of exchange rates and policies to avoid misalignment and reduce fluctuations as much as possible (Velasco, 1999), aiming to create an environment conducive to macroeconomic growth and business development.

The Nigerian government has adopted various exchange-rate regimes, since the establishment of the Bretton Woods system in 1947. Table 1 and Figure 1 show the various exchange-rate regimes adopted by Nigeria and their associated developments from 1957 to the present.

Table 1. Major developments in exchange-rate management regimes in Nigeria

\begin{tabular}{|c|c|c|c|c|}
\hline $\mathrm{S} / \mathrm{N}$ & PERIOD & $\begin{array}{l}\text { EXCHANGE-RATE } \\
\text { REGIME }\end{array}$ & MAJOR DEVELOPMENTS & $\begin{array}{l}\text { OUTCOMES/AVERAGE EXCHANGE } \\
\text { RATE }\end{array}$ \\
\hline 1 & $1957-1973$ & Fixed & $\begin{array}{l}\text {-Nigerian pound currency } \\
\text {-No devaluation } \\
\text {-BOP viability/oil boom began }\end{array}$ & Appreciation/(NP0.66/GBP) \\
\hline 2 & $1974-1985$ & Fixed & $\begin{array}{l}\text {-Naira was introduced } \\
\text {-First devaluation experience } \\
\text {-Import licensing regime and exchange control } \\
\text { measures }\end{array}$ & Naira depreciated/(NP0.66-N2.02/GBP) \\
\hline 3 & $1986-2014$ & Flexible/managed & $\begin{array}{l}\text {-FEM deregulation/dual exchange-rate system } \\
\text {-Bidding and auction of Forex } \\
\text {-CBN interventions }\end{array}$ & $\begin{array}{l}\text { Intense pressure on the naira and substantial } \\
\text { depreciation/exchange-rate range } \\
(\mathrm{N} 3.61-\mathrm{N} 4.04)) \\
(\mathrm{N} 4.04-\mathrm{N} 157) / \mathrm{US} \$\end{array}$ \\
\hline 4 & 2014-present & Managed float & $\begin{array}{l}\text {-Deliberate intervention and exchange control } \\
\text { measures } \\
\text {-Realignment of the naira } \\
\text {-BDC reform (stoppage of bidding) }\end{array}$ & $\begin{array}{l}\text { Stable interbank rate and widening BDC } \\
\text { rate; exchange-rate range: N180-197/US\$ }\end{array}$ \\
\hline
\end{tabular}

With the establishment of the Central Bank of Nigeria (CBN) in 1958, the pound sterling was adopted as the legal tender relative to the gold standard as a yardstick for international settlement. During this period, the CBN operated a fixed exchange-rate regime, with the US dollar serving as the backup for the gold standard (Ajakaiye \& Ojowu, 1994).

A major development during this period was the crisis in the early 1970s that affected the Bretton Woods system, which led to the devaluation of the US dollar and other major currencies. Despite such devaluation, the Nigerian pound appreciated from NP/US\$2.80 in 1971 to NP/US\$3.80 in 1973. This resulted from the huge inflow of petrodollars from the first oil boom in 1973.

The period 1973-1985 marked another milestone in the evolution of foreign exchange in Nigeria, as the naira replaced the Nigerian pound in 1973. This period was characterized by intense pressure to devalue the naira. Such pressure emanated from the assumption that the naira was overvalued relative to the anchor currency. As a result, the naira was devalued, thereby bringing the exchange rate to N0.66/US\$1. However, it recorded a slight appreciation by $0.2 \%$ to N0.62/US $\$ 1$ in 1974 , before moderating by $0.1 \%$ to an average of N0.64/US $\$ 1$ between 1975 and 1979 due to a fall in crude oil prices. 


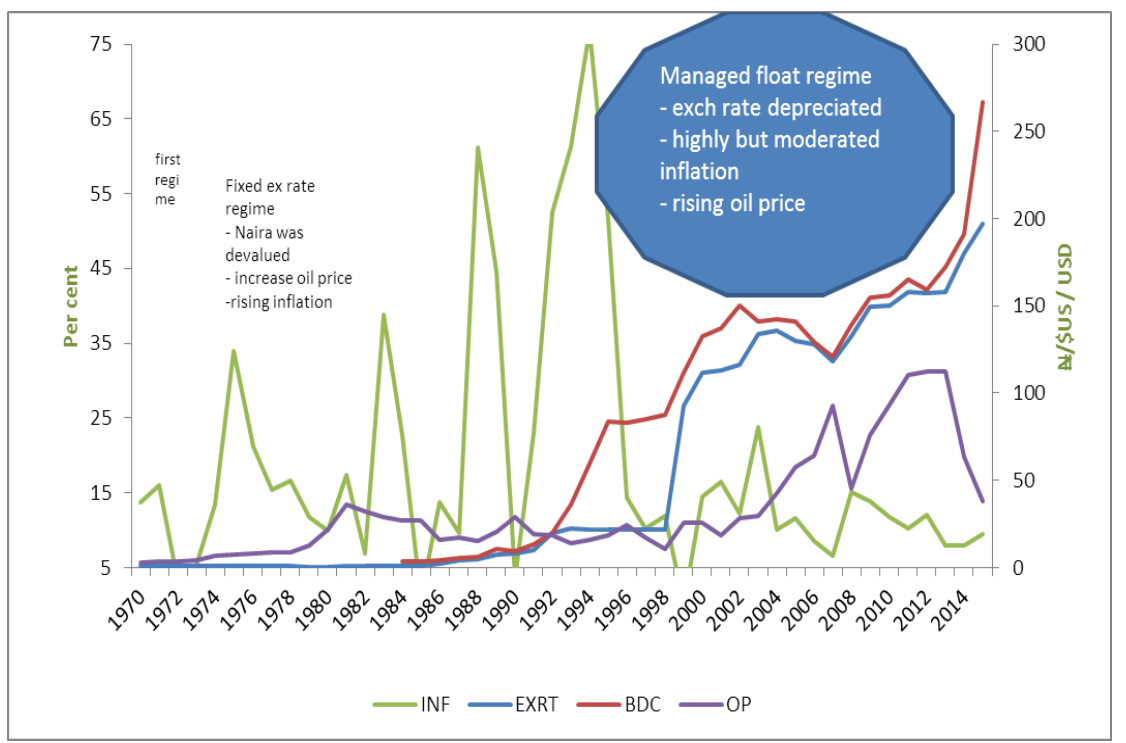

Figure 1. Exchange-rate regimes and key macroeconomic indicators

Source: CBN statistical Bulletin (various editions).

As foreign exchange earnings increased following improved oil prices, the naira appreciated to N0.55/US\$1 in 1980 before depreciating by $2.9 \%$ and $14.6 \%$ to N0.74 and N0.89/US\$1 in 1983 and 1985, respectively.

In 1986, the government introduced the Structural Adjustment Program (SAP) to liberalize the economy and eliminate structural distortions that hindered sustainable growth. A key aspect of SAP was the 1986 introduction of a flexible exchange-rate regime by the CBN (Adeoye \& Atanda, 2012; Nnanna, 2002).

Several variants of flexible exchange rates prevailed under SAP, reflecting the various degrees of deregulation of the foreign exchange market. The first was the introduction of the Second-Tier Foreign Exchange Market (SFEM) in 1986. This was followed by the Foreign Exchange Market (FEM) in 1987, Interbank Foreign Exchange Market (IFEM) in 1988, Autonomous Foreign Exchange Market (AFEM) in 1995, IFEM in 1999, and Dutch Auction System (DAS) in 2002. Due to the merger of the two tiers through the FEM, the demand for foreign exchange increased significantly, which led to the eventual depreciation of the naira.

The introduction of the IFEM allowed banks to trade with each other in the foreign exchange. However, the exchange rate recorded a 55.9\% depreciation from N0.89 in 1985 to N2.02 in 1986 and to N7.65/US\$ by the end of 1990. The heightened demand for the dollar led to a further depreciation to N22.69/US\$ in 1993 under the FEM before gaining relative stability at an average of N21.88/US\$ between 1994 and 1998 (Danmola, 2013). However, a fall in oil prices in the late 1990s, coupled with excess liquidity in the banking system and a persistent fiscal deficit, resulted in a depreciation of the naira by $76 \%$ from $\mathrm{N} 21.88 / \mathrm{US} \$ 1$ in 1998 to N92.69/US\$ in 1999. The aftermath of the 1997-1999 economic downturn contributed to a further depreciation of the naira to N116.12/US\$ in 2002. However, due to CBN market interventions, volatility in the parallel market rate was moderated during the period 1999-2002.

As part of the effort to stabilize the exchange rate, the CBN introduced the rDAS in 2002 and later adopted the wDAS in 2005. However, the global economic and financial crisis of 2008-2009, which preceded a fall in crude oil prices, led to a further depreciation of the naira from N149.58/US\$ in 2009 to N158.27/US\$ in 2011.

The reintroduction of the rDAS in 2012, as a part of policy measures to manage the post-crisis economy, led to a further depreciation of the naira to N180/US\$ in October 2014 following oil-price shocks. Since then, the exchange rate has shown persistent depreciation. An examination of the monthly exchange rate of the naira against the USD between 1991 and 2016 shows clear incidences of volatility (see Figure 2). 


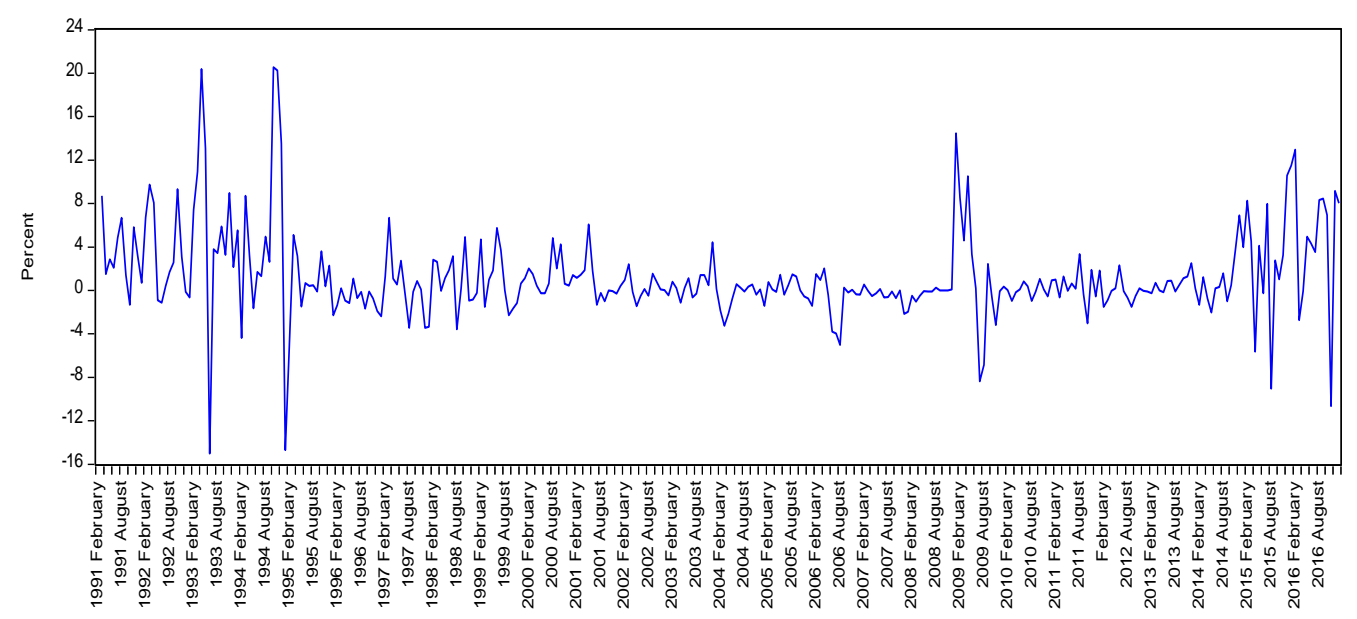

Figure 2. Return rates for BDC (1991-2016)

A major cause of volatility in the naira exchange rate can be traced to the volatile price of crude oil in the international market. This is the direct result of a monolithic economy that largely depends on crude oil revenues.

The naira came under intense pressure in 2014Q2, largely because of a drop in the price of oil, which led to a significant fall in external reserves. The outcome was a huge depreciation in the exchange rate with the interbank rate, depreciating from N160/US $\$ 1$ in 2014Q2 to N186/US $\$ 1$ by October 2014 and N216/US $\$ 1$ by January 2015.

During this period, Nigerian import bills averaged US $\$ 4.6$ billion, resulting in intensified capital flight and the further depletion of external reserves. The combined effects of these developments culminated in a $24.3 \%$ loss in external reserves, from US\$37 billion in December 2014 to US\$28 billion in January 2016. In effect, the foreign exchange market came under greater pressure with a further depreciation of the naira from N191.5 in December 2014 to N267 at the BDC segment. This also triggered inflationary pressure resulting from the country's high dependency on imports, as inflation rose to 9.6\% in January 2016 from 8.0\% in December 2014.

Due to frequent cases of sharp practices and abuse under the wDAS, the CBN formally replaced the window with the rDAS in February 2015. The reintroduced rDAS coincided with the CBN's direct sale of foreign exchange on the interbank foreign exchange market. Yet, the measures could not significantly reduce demand pressure, marginally improving accretion to external reserves between February and April 2015.

\section{Literature Review}

Following the liberalization of the global foreign exchange market, exchange-rate dynamics have received increased research attention. Special areas of research interest have included the causes of exchange-rate fluctuations, the existence of a significant long-run relationship between real exchange rates and other key economic indicators, and the effect of exchange-rate volatility shocks on economic growth (MacDonald \& Nagayasu, 1999).

The theoretical economic literature has identified several traditional causes of exchange-rate fluctuation. These include the effects of real domestic shocks on exchange-rate supply or demand, as well as the influence of real external shocks and nominal shocks on the money supply. The nexus between monetary policy and exchange rates has been at the forefront of international macroeconomics discourse. Myriad studies have examined the interplay between monetary policy and exchange-rate volatility in developed countries; however, developing countries have received less attention (An \& Sun, 2008; Faust \& Rogers, 1999; Lewis, 1995; Kaminsky \& Lewis, 1996).

According to the standard Dornbusch (1976) model, unplanned shocks emanating from monetary policy decisions significantly affect exchange rates. The Dornbusch (1976) exchange-rate overshooting hypothesis model predicts that a contractionary monetary policy shock will lead to an appreciation of the exchange rate. It is suggested that in the long run, depreciation of the currency can set in, following uncovered interest parity.

Real exchange-rate volatility has also been attributed to business-cycle shocks (Clarida \& Gali, 1994). To validate this, Gauthier and Tessier (2002) used a structural vector error correction model to assess the effect of supply shocks on real exchange-rate dynamics in Canada. They found that exchange-rate depreciation was 
largely caused by positive supply shocks. Meanwhile, Hausmann et al. (2006) suggested that real exchange-rate volatility is higher in developing economies relative to their industrialized counterparts, largely due to differences in exposure to shocks. However, Devereux and Lane (2003) found in a cross-country study that external financial liabilities such as foreign debts can reduce a country's exposure to external shocks and therefore minimize real exchange-rate volatility in developing countries.

The effects of devaluation on economic growth have also been widely studied. Orthodox stabilization programs have long recognized domestic currency devaluation as an important component of trade-policy reform. The devaluation of domestic currency helps to raise the price of traded goods compared to non-tradable goods. This will likely stimulate resource reallocation and the production of local substitutes for imported goods, depending on the capacity of the domestic economy (Khondker et al., 2012). Devaluations also help to enhance global competitiveness through the increased production of exportable products, since exports are cheaper relative to imports.

However, nominal devaluations increase import prices and therefore discourage citizen demand for imported goods. Devaluation in most cases helps to boost the external trade balance because of increased exports and reduced imports. Some developing economies, therefore, pursue currency devaluation to achieve a balance in payment challenges.

While some schools of thought propose that the increased production of traded and exportable goods, facilitated through devaluation, can enhance economic growth, others suggest that the accrued improvement in the trade balance, as a result of nominal devaluations, comes at a high cost. Some even argue that the indirect costs of devaluation could be far higher than the benefits and may therefore be inimical to overall output growth-a phenomenon popularly referred to as the contractionary effect of devaluation.

Economic theory offers three main explanations for the contractionary effect of devaluation from the demand side. First, the increase in the price of traded goods, as a result of devaluation, becomes a rise in the general price level, leading to a negative real balance effect. This results in reduced aggregate demand and output (Edwards, 1986). Second, devaluation could cause income redistribution, which is likely to contract growth. Diaz Alejandro (1963) pioneered this argument, explaining that the redistribution of income from those with a high marginal propensity to consume to those with a high propensity to save, negatively affects aggregate demand. Finally, devaluation could have contractionary effects on growth if there is an inelastic demand for imported goods due to the domestic country's inability to provide substitutes for imported capital and essential intermediate goods (Upadhaya \& Upadhaya, 1999). From the supply side, devaluation can adversely affect growth through the relatively high cost of imported inputs, which might reduce production output and profit margins (Lizondo \& Montiel, 1989).

Many studies have investigated the relationship between exchange-rate fluctuations and economic growth. Early studies include Gylfason and Schmid (1983), Connolly (1983), and Kamin and Klau (1988), which generally found that devaluations led to expansive growth. Subsequent studies, however, provided support for devaluation's contractionary effect on growth (Gylfason \& Radetzki, 1985; Odusola \& Akinlo, 2001; Berument \& Pasaogullari, 2003; El-Ramly \& Abdel-Haleim, 2008).

Other studies have reported mixed results. El-Ramly and Abdel-Haleim (2008), for example, found that the negative effects of exchange-rate fluctuations on growth lasted for several years before an expansionary effect could manifest. Edwards (1986) and Rhodd (1993), meanwhile, found a short-run contractionary effect and a long-run expansionary response.

Another strand of literature failed to find any significant growth in response to exchange-rate movements (e.g., Bahmani-Oskooee, 1998). Some multicountry studies have reported mixed findings. For instance, in a panel study involving 42 countries, Bahmani-Oskooee and Miteza (2006) found a contractionary effect of long-run devaluations in non-OECD countries and mixed results for OECD economies.

By contrast, some studies have investigated the effect of overvalued exchange rates on growth in developing economies. In this regard, there is overwhelming evidence that overvalued exchange rates negatively affect growth (Dollar, 1992; Easterly, 2005).

A more recent strand of literature has shown the positive effects of undervalued exchange rates on economic growth. Using a constructed index of undervaluation, Rodrik (2008) found that undervalued currencies could enhance growth; this was supported by successful cases of East Asian economies, especially China. This finding contrast sharply with the so-called Washington Consensus view that undervaluation can overheat the economy, cause excessive inflation, and adversely affect the overall economy (Berg \& Miao, 2010). Some recent studies 
have generally buttressed Rodrik's (2008) findings. For instance, Gluzmann et al. (2012) and Mbaye (2012) found a positive relationship between enhanced growth and undervaluation of the exchange rate. The only area of contention relates to the mechanism by which undervaluation fosters growth.

A recent study that used a general methods of moment (GMM) approach involving 45 countries found a contractionary effect of exchange-rate volatility on economic growth (Barguellil et al., 2018). Similarly, using a cointegration technique, Razzaque et al. (2017) found that a $10 \%$ depreciation in the real exchange rate in the long run was associated with a 3.2\% average rise in aggregate output in Bangladesh.

Meanwhile, using an autoregressive distributed lag (ARDL) cointegration estimation method, Obeng (2017) examined the effects of exchange-rate volatility on nontraditional exports in Ghana. This study found that exchange-rate volatility had negative effects on Ghana's nontraditional exports, with the effects being more pronounced in the long run than in the short run. Similarly, Phiri (2018) investigated the traditional assumption of a linear relationship between exchange-rate volatility and economic growth in South Africa using smooth transition regression (STR) and found a nonlinear relationship between exchange-rate volatility and economic growth. That study noted, however, that the regime-switching behavior of the South African Reserve Bank is facilitated by government size, and that exchange-rate volatility has a significant influence on economic growth, especially when the government's expenditure growth is below $6 \%$. Nonetheless, the author concluded that the extent to which exchange-rate movement can affect economic growth depends largely on how fiscal authorities respond to external sector shocks.

Khan et al. (2019) used ARDL bounds testing to investigate the effect of macroeconomic variables on the USD/CYN exchange rate using China's annual data from 1980 to 2017. The results showed that trade openness and GDP growth had a positive effect on the USD/CNY exchange rate while inflation and interest rates had a negative effect.

Studies have employed different methods to estimate the negative effect of exchange-rate volatility on Nigeria's economic growth (Oloyede \& Fapetu, 2018; Eneji et al., 2018;). Meanwhile, using the Johansen cointegration method, Iyeli and Utting (2017) found a long-run positive relationship between exchange-rate volatility and economic growth in Nigeria. Using GARCH, Dickson (2012) used annual data (1970-2009) to evaluate the effect of exchange-rate volatility on economic growth in Nigeria and found that economic growth responded positively to exchange-rate volatility in the short run but negatively in the long run. Similarly, using ordinary least squares, Owolabi and Adegbite (2013) analyzed annual data from 1991 to 2010 and found that exchange-rate volatility adversely affected Nigeria's economy in terms of imported and exported goods. Using GARCH and ARDL bounds testing on cointegration, Yakub, Sani, Obiezue, and Aliyu (2019) evaluated the effect of exchange-rate volatility on trade flow in Nigeria and found that it had negative effects in the short run but no such effects in the long run. Nsofor, Takon, and Ugwuegbe (2017) similarly explored the effects of exchange-rate volatility on Nigeria's economic growth using GARCH $(1,1)$ and GMM and, like many others, found that volatility and FDI had a significant negative effect on economic growth. Using VECM, Adelowokan, Adesoye, and Balogun (2015) also found that exchange-rate volatility negatively affected investment and economic growth in Nigeria.

Despite an abundance of literature on the nexus between exchange-rate volatility and economic growth in Nigeria, the results have been mixed. For example, Lawal, Atunde, Ahmed, and Asaleye (2016) found no effect of exchange-rate fluctuation on economic growth in the long run, though they did find evidence of a short-run relationship. Emerah, Adeleke, and David (2015) and Iyeli (2017), meanwhile, found a direct positive relationship between exchange-rate volatility and economic growth; however, their findings were counterintuitive with theoretical assumptions and did not seem to have a strong grounding. For the most part, however, volatility has been found to have an adverse effect on economic growth in Nigeria. To our knowledge, no previous study in this area has used a combined GARCH and vector error correction model. Also, our choice of variables (i.e., interbank exchange rate, money stock, prime lending rate, and headline CPI) differentiate our study from the others, thus filling a gap in the literature.

\section{Model Specification}

\subsection{Estimating Exchange-Rate Volatility}

Theoretically speaking, there is little consensus among economists regarding a unified exchange-rate theory. Musyoki et al. (2012) noted five such theories, which they classified as either traditional or modern, with traditional concepts anchored in trade and financial flows and purchasing power parity. These theories, the authors suggested, are useful for explaining long-run changes in exchange rates; they include the following: the elasticity method of exchange-rate determination, the monetary method of determining exchange rates, the 
portfolio balance approach, and the purchasing power theory of exchange-rate estimation. The authors described "modern" theories as focusing on capital flows, with an inherent capability to explain short-run volatility, with a long-run overshooting tendency.

Different statistical methods have been used in the literature to extract exchange-rate volatility. The present study used generalized autoregressive conditional heteroscedasticity (GARCH) and the moving standard deviation of exchange-rate times series to generate volatility, as widely documented in the literature (Khosa et al., 2015; Arize et al., 2000; Mpofu, 2016; Serenis \& Tsounis, 2015; Musyoki et al., 2012). The following general expression is used:

$$
\delta_{t+n}=\left[\left(\frac{1}{n}\right) \sum_{i=1}^{n}\left(E X R_{t+i-1}-E X R_{t+i-2}\right)^{2}\right]^{\frac{1}{2}}
$$

where $\mathrm{EXR}_{\mathrm{t}+\mathrm{i}}$ denotes the exchange rate at time $\mathrm{t}+\mathrm{i}$. Despite some advantages of the standard deviation method for extracting exchange-rate volatilities (exchange-rate risk via capturing temporary variation in the absolute magnitude of changes in the real exchange rate), the technique has been criticized for its inaccurate assumption of normality in the empirical distribution and its inability to distinguish between predictable and unpredictable elements in exchange-rate processes (Takandesa et al., 2006; Fourie et al., 2016).

\subsection{Growth Analysis}

To determine whether exchange-rate volatility affects economic growth in Nigeria, based on the review of the literature and theoretical frameworks, we express the economic growth function as follows:

$$
G D P=f(\text { LIBR, LM 1, LCPI, PLR, LERVOL })
$$

where LIBR is the log of the interbank exchange rate, a semiofficial Forex window; LM1 is the log of the narrow money supply; LCPI is the log of the consumer price index; PLR is the prime lending rate; and LERVOL is the $\log$ of the average monthly value of daily conditional heteroscedasticity for US\$/NGA exchange-rate volatility, which was generated in the EGARCH environment and then plugged into our model. The choice of these regressors to represent output growth was informed by the transmission channels through which each could affect the country's economic growth. The interbank exchange rate (exchange-rate channel) is believed to affect growth through its effect on the domestic currency value, domestic inflation, the external sector, macroeconomic policy credibility, capital flows, and financial stability. Money stock affects growth through the interest rate channel, especially in the short run. The pass-through effect of inflation can be felt through credit/interest rate channels and ultimately the asset price channel while the prime lending rate affects growth through the credit channel. The data, including those for GDP, are monthly, from January 2003 to June 2017. All data were obtained from the CBN.

Our model takes the following generalized form:

$$
G D P_{n}=\alpha_{0}+\alpha_{1} \gamma_{n}+\alpha_{2} L_{E R V O L}+\varepsilon_{n}
$$

$\mathrm{GDP}_{n}$ represents economic growth, $\mathrm{Y}_{\mathrm{n}}$ represents growth causative parameters, $\mathrm{ERVOL}_{\mathrm{n}}$ in its $\log$ form captures exchange-rate volatility, and $\varepsilon_{\mathrm{n}}$ is the stochastic error term.

A growing number of authors have come to rely on the GARCH model popularized by Bollerslev (1986) as a reliable framework for measuring exchange-rate volatility (Fourie et al., 2016). This model is considered superior to the standard deviation model described earlier, given that it is more parsimonious and can overcome the issue of overfitting. In addition, the GARCH model captures time-varying conditional variance as a variable derived from a time series model of the conditional mean and variance of the growth rate, thus making it more suitable for explaining volatility clustering (Chowdury, 2005). This model assigns exponentially regressive weights to past observations in the data, allowing recent shocks to have more of an impact on the model. The estimated GARCH $(1,1)$ for this model follows the autoregressive (AR) model of the real effective exchange rate (REER) of order 1 and takes the following form:

$$
\begin{gathered}
\text { REER }_{t}=\Lambda_{0}+\Lambda_{1}+\operatorname{REER}_{t-1}+\varepsilon_{t} \\
\varepsilon_{t} / \Omega_{t-1} \sim \operatorname{iid}\left(0, \delta_{t}{ }^{2}\right) \\
\delta_{t}{ }^{2}=\varphi+\alpha(\lambda) \delta^{2}{ }_{t-k}+\beta(\lambda) \eta_{t}{ }^{2}
\end{gathered}
$$

where $\Omega$ represents information set; $\delta_{t}^{2}$ is the weighted average of past squared deviations, which gradually declines but never reaches zero, $\delta_{t}^{2} \neq 0$ (the conditional variance); $\alpha(\lambda)$ and $\beta(\lambda)$ are polynomials with lag operators; and $\eta$ represents innovation. Invariably, the expansion of equation (5) takes the following form: 


$$
\delta_{t}{ }^{2}=\varphi+\sum_{i=1}^{m} \alpha_{i} \delta^{2}{ }_{t-1}+\sum_{i=1}^{n} \beta_{j} \eta^{2}{ }_{t-j} .
$$

Our empirical GARCH $(1,1)$ is therefore taken from equation (6) and takes the following form:

$$
\delta_{t}^{2}=\varphi+\alpha_{1} \delta_{t-1}^{2}+\beta_{1} \eta_{0}
$$

The estimated conditional variance $\delta_{t}^{2}$ in equation (8) is the second proxy measure of exchange-rate volatility. Similarly, the autoregressive root present in the volatility shock persistence is the sum of the parameter coefficient $\alpha+\beta$. If $\alpha+\beta \geq 1$, it indicates the presence of volatile behavior in the series.

\subsection{Vector Error Correction Model (VECM)}

This study used the vector autoregressive (VAR) model, as introduced by Sims (1980). This model has become widely accepted among macroeconomists as a method for time-series modeling, especially to evaluate joint dynamic behavior between given variables lacking the restrictions required to identify underlying structural parameters.

A cointegration test was conducted in accordance with Johansen (1988). The results are presented in Table 5. Both the trace test and the maximum eigenvalue statistics rejected the null hypothesis of $r \leq 0$, against the alternative hypothesis $r \geq 1$ at the $5 \%$ level of significance, evidencing the presence of at least one cointegrating vector in the model.

The VAR of the order p model can be expressed as follows:

$$
\Delta_{t}=\beta+\mathrm{A}_{1} Y_{t-1+---------+} A_{p-1} Y_{t-p}+\varepsilon_{t}
$$

Given that VAR can be written in VECM form provided the variables are of I (1) order of integration,

$$
\Delta Y_{t}=\beta_{0}+\beta y_{t-1}+\beta_{1} \Delta y_{t-1}+\beta_{2} \Delta y_{t-2}+\ldots \ldots+\beta_{p-1} \Delta y_{t-p+1}+\lambda y_{t-p}+\varepsilon_{t}
$$

where $\beta_{0}$ is an $(\mathrm{nx} 1)$ vector of intercepts with elements $\beta_{i 0}$, and $\beta_{i}$ is $(n \times n)$ coefficient matrices with elements $\beta_{i 0}(i)$. Meanwhile, $\varepsilon_{0} \sim \operatorname{iid}\left(\mu(0), \delta^{2}(k)\right)$, where iid are independent and identically distributed random variables, $\mu$ is the mean, $\delta^{2}$ is the variance, and $k$ is a constant. Hence, if $\beta$ is of $\operatorname{rank} 1<r<n$, it can be decomposed into $\beta=\lambda \pi^{\prime}$, where $\pi$ is the matrix of cointegrating vectors, and $\lambda$ is the matrix of adjustment:

$$
\Delta y_{t}=\beta_{0}+\beta y_{t-1}+\beta_{1} \Delta y_{t-1}+\beta_{2} \Delta y_{t-2}+\ldots .+\beta_{p-1} \Delta y_{t-p+1}+\lambda\left(\mu^{\prime} y_{t-p}\right)+\varepsilon_{t}
$$

The term $\lambda \mu^{\prime} y_{t-p}$ is the linear combination process. According to Engle and Granger (1987), when a set of variables is I (1) and is cointegrated, then a short-run analysis of the system should incorporate the error correction term (ECT) to model the adjustment for the deviation from its long-run equilibrium. The VECM is therefore characterized by both differenced and long-run equilibrium models, thereby allowing for estimates of short-run dynamics as well as long-run equilibrium adjustments processes. In this study, given that $N$ represents the number of variables, the VECM is expressed as follows:

$$
\begin{gathered}
\Delta \gamma_{t}=\alpha_{1}+\alpha_{1} \xi_{1}+\sum_{i=0}^{N} \beta_{i} \gamma_{t-i}+\sum_{i=0}^{N} \psi_{i} \Delta \chi_{t-i}+\sum_{i=0}^{N} \gamma_{i} \mathrm{Z}_{t-i} \\
\Delta \chi_{t}=\alpha_{2}+\alpha_{2} \xi_{t-1}+\sum_{i=0}^{N} \beta_{i} \gamma_{t-1}+\sum_{i=0}^{N} \psi_{i} \Delta \chi_{t-i}+\sum_{i=0}^{N} \gamma_{i} \mathrm{Z}_{t-i}
\end{gathered}
$$

$\xi_{t-1}$ represents the ECT lagged one period. Ang and McKibbin (2007) identified two sources of causation: through the ECT $(\beta \neq 0)$ and through the lagged dynamic terms. This implies that two separate Granger causality tests can be performed using the VECM framework: long-run causality through the weak exogeneity test and the short-run Granger noncausality test between variables, leveraging the Wald test (Tule et al., 2020 and Ebuh et al., 2019).

If the coefficient of the ECT, which in the above equations is represented by $\xi_{t-1}$, is negative and significant, it implies that temporary variations between dependent and independent variables are expected to result in a stable long-run relationship.

The following equations represent a general specification of the Granger causality test in a typical bivariate (X, Y) model:

$$
\begin{aligned}
& \gamma_{t}=\alpha_{0}+\alpha_{1} \gamma_{t-1}+\ldots .+\alpha_{i} \gamma_{t-i}+\beta_{1} \chi_{t-1}+\ldots .+\beta_{i} \chi_{t-i}+\varepsilon \\
& \chi_{t}=\alpha_{0}+\alpha_{1} \chi_{t-1}+\ldots .+\alpha_{i} \chi_{t-i}+\beta_{1} \gamma_{t-1}+\ldots .+\beta_{i} \gamma_{t-1}+\varepsilon
\end{aligned}
$$


The subscript represents time periods, and $\varepsilon$ is the stochastic term. The parameter " 0 " represents the constant growth rates of $\mathrm{Y}$ and $\mathrm{X}$. Hence, the general movement of cointegration between $\mathrm{X}$ and $\mathrm{Y}$ variables in line with the unit root process is depicted by the trend in equations 14 and 15 .

\subsection{Interpretation of Results}

Stationarity test: The results in Table 2 indicate that our time series data are of the integrated order I (1) at level; that is, we rejected the null hypothesis that there is a unit root, indicating that our data are nonstationary at level. However, the second columns for both ADF and PP indicate acceptance of the null hypothesis that there is a unit root for all-time series at their first difference, given that the values of the augmented Dickey-Fuller (ADF) and Phillip-Perron (PP) test statistics are less than their critical values at $1 \%$ and $5 \%$ levels of significance. As such, the variables became stationary with no trace of unit root at their first difference.

Table 2. Conventional Unit Root Tests

\begin{tabular}{lcccc}
\hline & \multicolumn{2}{c}{ ADF } & Level & $1^{\text {st }}$ Difference \\
\cline { 2 - 5 } & Level & $1^{\text {st }}$ Difference & 0.8431 & $-9.5762^{* * *}$ \\
IBR & 0.3469 & $-9.7098^{* * *}$ & -0.1105 & $-15.0493 * * *$ \\
RYG & -0.3018 & $-11.8238^{* * *}$ & -2.0192 & $-9.3151^{* * *}$ \\
ERVOL & -2.1544 & $-9.2356^{* * *}$ & -1.7589 & $-15.5637 * * *$ \\
PLR & -1.5516 & $-12.4536 * * *$ & $-3.2726 * *$ & $-11.1029 * * *$ \\
CPI & $-3.2204 * *$ & $-11.0791^{* * *}$ & 5.5996 & $-7.1660^{* * *}$ \\
\hline
\end{tabular}

Note. The unit root tests were performed using the constant term without trend. $* * *$ denotes acceptance of the null hypothesis that there is a unit root at the $1 \%$ level of significance, while ** denotes acceptance at the 5\% level. Both the augmented Dickey-Fuller (1981 ADF) and Phillip-Peron (1988, PP) tests were conducted, following Jenkins and Katircioglu (2011) and in accordance with Enders and Granger (1998). Tests were carried out using Eviews 9.

The Ng-Perron unit root test corrects the low testing power of conventional unit root tests when the root of the autoregressive polynomial is close to unity (Dejong et al., 1992; Esteve \& Tumarit, 2012; Kim, 2017). However, there is the possibility of a large distortion occurring because of the moving average polynomial of a first-order difference time series analysis having a large negative autoregressive root (Perron \& Ng, 1996). To address this, $\mathrm{Ng}$ and Perron (2001) proposed a method consisting of modified tests, described as $M_{M A I C}^{G L S}\left(\mathrm{MZ}_{\mathrm{a}}, \mathrm{MZ}_{\mathrm{t}}, \mathrm{MSB}\right.$, and MPT), with generalized least squares (GLS) data detrending and a modified Akaike information criterion (MAIC), as proposed by Elliot et al. (1996).

Table 3. Ng-Perron Unit Root Tests

\begin{tabular}{|c|c|c|c|c|c|}
\hline & & $\mathrm{MZ}_{\mathrm{a}}$ & $\mathrm{MZ}_{\mathrm{t}}$ & MSB & MPT \\
\hline \multirow[t]{2}{*}{ LIBR } & Level & 2.1818 & 0.8329 & 0.3818 & 18.5250 \\
\hline & $1^{\text {st }}$ difference & $-76.8097 * * *$ & $-6.1966^{* * *}$ & $0.0807 * * *$ & $0.3202 * * *$ \\
\hline \multirow[t]{2}{*}{ LM1 } & Level & 1.4271 & 1.4975 & 1.0493 & 82.7829 \\
\hline & $1^{\text {st }}$ difference & $-126.192 * * *$ & $-7.9432 * * *$ & $0.0629 * * *$ & $0.1944 * * *$ \\
\hline \multirow[t]{2}{*}{ RYG } & Level & 0.11279 & 0.7505 & 0.5097 & 20.0972 \\
\hline & $1^{\text {st }}$ difference & -0.2299 & -0.1517 & 0.6599 & 26.9006 \\
\hline \multirow[t]{2}{*}{ LERVOL } & Level & 1.7432 & 0.5521 & 0.3167 & 14.3095 \\
\hline & $1^{\text {st }}$ difference & $-88.7104 * * *$ & $-6.6584 * * *$ & $0.0751 * * *$ & $0.2855^{* * *} *$ \\
\hline \multirow[t]{2}{*}{ PLR } & Level & -0.5325 & -0.3957 & 0.7432 & 29.9279 \\
\hline & $1^{\text {st }}$ difference & $-52.7322 * * *$ & $-5.1279 * * *$ & $0.0972 * * *$ & 0.4820 *** \\
\hline \multirow[t]{2}{*}{ LCPI } & Level & 3.0063 & 8.6170 & 2.8663 & 753.3420 \\
\hline & $1^{\text {st }}$ difference & 2.1256 & 2.1027 & 0.9893 & 83.8662 \\
\hline
\end{tabular}

Note. The unit root tests were performed using the constant term without trend. $* * *$ denotes the rejection of the null hypothesis that there is a unit root at the $1 \%$ level of significance; the critical values refer to $\mathrm{Ng}$ and Perron (2001).

\subsection{Cointegrating Vectors Estimation}

Cointegration estimation involves using Johansen's unit root method, which tests two different statistics - the "trace test statistic" and the "maximum eigenvalue test statistic"- to establish the number of cointegrating 
vectors. The trace statistic examines the null hypothesis that the number of divergent cointegrating relationships is $\leq$ ' $r$ ' against the alternative hypothesis of ' $r$ ' cointegrating relationships, as expressed below:

$$
\theta_{\text {Trace }}(r)=-N \sum_{j=r+1}^{P} \ln \left(1-\hat{\theta}_{j}\right)
$$

The likelihood ratio for testing the null hypothesis of at most ' $r$ ' cointegrating vectors against the alternative $(r+1)$ is depicted as follows:

$$
\theta_{\max (r, r,+1)}=-N \ln \left(1-\hat{\theta}_{r}+1\right)
$$

Where $\theta_{i}$ represents the eigenvalues, and ${ }_{N}$ is the total number of observations. In line with Johansen (1988), the trace and maximum eigenvalue statistics have nonstandard distributions under the null hypothesis, and they provide approximate critical values for the statistic generated under the Monte Carlo method. When trace and maximum eigenvalue statistics conflict, the trace test results should be considered superior.

Table 4. Lag order selection

\begin{tabular}{ccccccc}
\hline \multicolumn{2}{l}{ Sample: $2003 \mathrm{M} 01-2017 \mathrm{M} 06$} & \multicolumn{6}{c}{ Number of Selections: 160} \\
\hline Lag & LogL & LR & FPE & AIC & SC & HQ \\
\hline 0 & -5769.629 & NA & $1.52 \mathrm{e}+25$ & 75.00816 & 75.12649 & 75.05623 \\
1 & -4355.632 & 2699.447 & $2.56 \mathrm{e}+17$ & 57.11211 & 57.94037 & 57.44855 \\
2 & -4181.845 & 318.2340 & $4.29 \mathrm{e}+16^{*}$ & 55.32266 & $56.86086^{*}$ & $55.94747^{*}$ \\
3 & -4167.111 & 25.83296 & $5.68 \mathrm{e}+16$ & 55.59884 & 57.84697 & 56.51203 \\
4 & -4138.347 & 48.18919 & $6.31 \mathrm{e}+16$ & 55.69281 & 58.65088 & 56.89437 \\
5 & -4105.066 & 53.16173 & $6.64 \mathrm{e}+16$ & 55.72814 & 59.39614 & 57.21807 \\
6 & -4054.129 & 77.39799 & $5.60 \mathrm{e}+16$ & 55.53415 & 59.91209 & 57.31246 \\
7 & -4001.085 & $76.46619^{*}$ & $4.64 \mathrm{e}+16$ & $55.31280^{*}$ & 60.40068 & 57.37948 \\
8 & -3976.907 & 32.96981 & $5.67 \mathrm{e}+16$ & 55.46633 & 61.26415 & 57.82139 \\
\hline
\end{tabular}

Table 4 shows the lag-order selection statistics. As shown, a lag order of 2 was the recommended optimum; as such, all subsequent tests were carried out with a lag length order of (2).

Table 5. Johansen Cointegration test

\begin{tabular}{cccccc}
\hline \multicolumn{2}{l}{ VAR $=(\mathrm{RYG}, \mathrm{IBR}, \mathrm{LM} 1, \mathrm{PLR}, \mathrm{LCPI}, \mathrm{LERVOL}) ; \mathrm{Lag}=2$} & \multicolumn{5}{c}{} \\
\hline Null & Alternative & $\boldsymbol{\lambda}$ Trace & $\mathbf{9 5 \%}$ Critical Value & $\boldsymbol{\lambda}$ Max & $\mathbf{9 5 \%}$ Critical Value \\
\hline $\mathbf{r}=\mathbf{0}$ & $\mathrm{r} \geq 1$ & $155.57 * * *$ & 95.75 & $83.22 * * *$ & 40.08 \\
$\mathbf{r} \leq \mathbf{1}$ & $\mathrm{r} \geq 2$ & 72.34 & 69.82 & 31.06 & 33.88 \\
$\mathbf{r} \leq \mathbf{2}$ & $\mathrm{r} \geq 3$ & 41.28 & 47.86 & 21.11 & 27.58 \\
$\mathbf{r} \leq \mathbf{3}$ & $\mathrm{r} \geq 4$ & 20.17 & 29.80 & 14.81 & 21.13 \\
$\mathbf{r} \leq \mathbf{4}$ & $\mathrm{r} \geq 5$ & 5.36 & 15.49 & 5.35 & 14.26 \\
$\mathbf{r} \leq \mathbf{5}$ & $\mathrm{r} \geq 6$ & 0.01 & 3.84 & 0.01 & 3.84 \\
\hline
\end{tabular}

Cointegration rank (matrix D rank) was assessed using the Johansen method. This approach produces two likelihood estimators for the cointegration rank: a trace test and a maximum eigenvalue test (Table 5). The trace statistic could either reject the null hypothesis of no cointegration among the variables or fail to reject the null hypothesis, invariably attesting to the presence of at least one cointegration among the variables. Our results showed a rejection of the null hypothesis of no cointegration at the $5 \%$ level of significance. In our test, $\mathrm{H}_{0}: \mathrm{r}=0$ is rejected, but $\mathrm{H}_{0}: \mathrm{r} \leq 1$ is not rejected at the $5 \%$ level $(31.06<33.88)$. In effect, this trace test confirmed by the maximum eigenvalue that our variables failed to accept the null hypothesis that none of the variables is cointegrated. As such, the final established number of cointegrated vectors with 2 lags is equal to 1; that is, both $\lambda_{\text {trace }}$ and $\lambda_{\max }=1$. Given that the rank being equal to 1 is greater than 0 but less than the number of variables, the series is considered cointegrated. As such, we proceed with our estimation using the VECM model. 
Table 6. Vector error correction model

\begin{tabular}{|c|c|c|c|c|c|c|}
\hline Error Correction & $\mathrm{D}(\mathrm{RYG})$ & $\mathrm{D}(\mathrm{LCPI})$ & $\mathrm{D}(\mathrm{LM} 1)$ & $\mathrm{D}(\mathrm{LIBR})$ & $\mathrm{D}$ (PLR) & $\mathrm{D}$ (LERVOL) \\
\hline \multirow[t]{2}{*}{ CointEq1 } & -0.030452 & -0.000431 & 0.001450 & -0.004375 & -0.002014 & 0.003102 \\
\hline & {$[-2.44868]$} & {$[-0.47195]$} & [0.60195] & {$[-3.21242]$} & {$[-4.26247]$} & [0.84586] \\
\hline \multirow[t]{2}{*}{$\mathrm{D}(\mathrm{RYG}(-1))$} & 0.602367 & 0.006948 & -0.035211 & $-5.94 \mathrm{E}-05$ & -0.004936 & -0.066396 \\
\hline & [7.56175] & [1.18844] & {$[-2.28223]$} & {$[-0.00681]$} & {$[-1.63065]$} & {$[-2.82663]$} \\
\hline \multirow[t]{2}{*}{$\mathrm{D}(\mathrm{RYG}(-2))$} & 0.006990 & -0.002975 & 0.030206 & -0.003582 & 0.000409 & -0.049814 \\
\hline & {$[0.08715]$} & {$[-0.50536]$} & [1.94460] & {$[-0.40779]$} & {$[0.13418]$} & {$[-2.10638]$} \\
\hline \multirow[t]{2}{*}{ D(LCPI(-1)) } & 0.665045 & 0.074135 & 0.044513 & -0.149893 & -0.096290 & 0.680986 \\
\hline & [0.59958] & [0.91069] & {$[0.20721]$} & {$[-1.23404]$} & {$[-2.28455]$} & [2.08210] \\
\hline \multirow[t]{2}{*}{$\mathrm{D}(\mathrm{LCPI}(-2))$} & -1.220953 & 0.047165 & -0.126736 & -0.084678 & 0.000978 & -0.036478 \\
\hline & {$[-1.07738]$} & {$[0.56707]$} & {$[-0.57741]$} & {$[-0.68233]$} & {$[0.02272]$} & {$[-0.10916]$} \\
\hline \multirow[t]{2}{*}{$\mathrm{D}(\mathrm{LM} 1(-1))$} & -0.902081 & -0.013175 & -0.260588 & 0.002386 & -0.014294 & -0.095245 \\
\hline & {$[-2.27168]$} & {$[-0.45206]$} & {$[-3.38825]$} & [0.05487] & {$[-0.94730]$} & {$[-0.81341]$} \\
\hline \multirow[t]{2}{*}{ D(LM1(-2)) } & -0.094815 & 0.009961 & -0.303570 & -0.045938 & -0.036532 & 0.061584 \\
\hline & {$[-0.23845]$} & [0.34134] & [-3.94182] & [-1.05499] & {$[-2.41776]$} & [0.52524] \\
\hline \multirow[t]{2}{*}{ D(LIBR(-1)) } & 0.005433 & 0.123409 & -0.098767 & 0.197505 & -0.027090 & 1.742247 \\
\hline & {$[0.00727]$} & [2.25024] & {$[-0.68244]$} & [2.41358] & {$[-0.95401]$} & [7.90690] \\
\hline \multirow[t]{2}{*}{$\mathrm{D}(\operatorname{LIBR}(-2))$} & -0.317050 & 0.066221 & 0.150179 & -0.147761 & -0.019652 & 0.003673 \\
\hline & {$[-0.35184]$} & [1.00129] & [0.86047] & [-1.49735] & {$[-0.57390]$} & [0.01382] \\
\hline \multirow[t]{2}{*}{$\mathrm{D}(\operatorname{PLR}(-1))$} & -1.167392 & 0.023306 & -0.170646 & -0.002217 & 0.179947 & 1.239801 \\
\hline & {$[-0.57549]$} & {$[0.15654]$} & {$[-0.43434]$} & {$[-0.00998]$} & [2.33445] & {$[2.07271]$} \\
\hline \multirow[t]{2}{*}{$\mathrm{D}(\operatorname{PLR}(-2))$} & 0.681175 & -0.071744 & 0.883773 & 0.008004 & -0.030073 & 0.315262 \\
\hline & {$[0.34850]$} & {$[-0.50013]$} & [2.33456] & [0.03739] & {$[-0.40489]$} & [0.54699] \\
\hline \multirow[t]{2}{*}{ D(LERVOL1(-1)) } & -0.033671 & -0.000683 & -0.138666 & 0.009845 & 0.009935 & -0.036855 \\
\hline & {$[-0.12063]$} & {$[-0.03334]$} & {$[-2.56492]$} & {$[0.32206]$} & [0.93660] & {$[-0.44776]$} \\
\hline \multirow[t]{2}{*}{ D(LERVOL1(-2)) } & -0.055451 & -0.014216 & -0.031802 & 0.008421 & -0.001775 & -0.026476 \\
\hline & {$[-0.25096]$} & {$[-0.87666]$} & {$[-0.74314]$} & [0.34803] & {$[-0.21137]$} & {$[-0.40636]$} \\
\hline \multirow[t]{2}{*}{$\mathrm{C}$} & 0.001710 & -0.001204 & 0.012773 & 0.004832 & 0.008846 & -0.022965 \\
\hline & [0.05029] & {$[-0.48236]$} & [1.93925] & [1.29741] & [6.84498] & [-2.29009] \\
\hline R-squared & 0.408542 & 0.101930 & 0.188750 & 0.148729 & 0.224281 & 0.398684 \\
\hline Adj. R-squared & 0.359568 & 0.027567 & 0.121577 & 0.078241 & 0.160050 & 0.348894 \\
\hline F-statistic & 8.341991 & 1.370712 & 2.809889 & 2.110003 & 3.491767 & 8.007235 \\
\hline
\end{tabular}

Note. figures in brackets [] represent t-statistics.

The VECM results in Table 6 show that our variables conformed to the a priori expectation, with appropriate signage and evidence of stability in the model. Subsequently, the vector ECT, as shown by the cointegration equation, carries the a priori negative sign and is statistically significant, thus reflecting a low speed of adjustment toward the equilibrium position. Our estimation results show that the response variables, as shown by the R-squared, account for about $41 \%$ of variation in economic growth in Nigeria. As can be seen from the results, there is a negative relationship between exchange-rate volatility and economic growth, at least in the short run. Similarly, narrow money also shows a negative but significant relationship with GDP growth. As such, a $1 \%$ increase in narrow money (M1) stock can narrow economic growth by about $0.9 \%$ in the first lag period, and that effect even increased slightly in the second lag period. The entire model can be said to be statistically significant given the high F-statistic rates.

\subsection{Granger Causality}

Given that cointegration between two variables does not necessarily indicate the direction of the relationship, it is suggested that there must be Granger causality in at least one direction (unidirectional). As such, Table 7 checks for any such causality among the variables. The results corroborate the vector error correction results - namely, that a unidirectional relationship exists between exchange-rate volatility and economic growth. The same unidirectional causality is found between money supply and economic growth. However, the results showed no relationship in any direction between the interbank exchange rate and growth - an indication that the official window has little effect on economic activities in the country. Similarly, no causality was observed in any direction between the prime lending rate and economic growth. This indicates a disconnect between interest rates available only to high-net-worth economic agents and productive reality in the country. 
Table 7. VEC Granger Causality/Block Exogeneity/Wald Tests

\begin{tabular}{|c|c|c|c|}
\hline Hypothesis: A & Short-run Granger noncausality & Hypothesis: B & Short-run Granger noncausality \\
\hline Ho: $\Delta \mathrm{LCPI} \rightarrow \Delta \mathrm{RYG}$ & $\left(\right.$ all $\left.\beta_{11 i}=0\right)$ & Ho: $\Delta \mathrm{RYG} \rightarrow \Delta \mathrm{LCPI}$ & $\left(\right.$ all $\left.\beta_{11 i}=0\right)$ \\
\hline Chi-square & 1.4205 & Chi-square & 1.4723 \\
\hline Ho: $\Delta \mathrm{LM} 1 \neq \Delta \mathrm{RYG}$ & $\left(\right.$ all $\left.\beta_{21 i}=0\right)$ & Ho: $\Delta \mathrm{RGY} \rightarrow \Delta \mathrm{LM} 1$ & $\left(\right.$ all $\left.\beta_{21 i}=0\right)$ \\
\hline Chi-square & $5.2637 *$ & Chi-square & $5.753^{*}$ \\
\hline Ho: $\Delta \mathrm{LIBR} \rightarrow \Delta \mathrm{RYG}$ & $\left(\right.$ all $\left.\beta_{21 i}=0\right)$ & Ho: $\Delta \mathrm{RYG} \rightarrow \Delta$ LIBR & $\left(\right.$ all $\left.\beta_{21 i}=0\right)$ \\
\hline Chi-square & 0.1260 & Chi-square & 0.2608 \\
\hline Ho: $\Delta \mathrm{PLR} \rightarrow \Delta \mathrm{RYG}$ & $\left(\right.$ all $\left.\beta_{31 i}=0\right)$ & Ho: $\Delta \mathrm{RYG} \rightarrow \Delta \mathrm{PLR}$ & $\left(\right.$ all $\left.\left.\beta_{31 i}=0\right)\right)$ \\
\hline Chi-square & 0.3881 & Chi-square & 3.7181 \\
\hline Ho: $\Delta \mathrm{RYG} \rightarrow \Delta$ LERVOL & $\left(\right.$ all $\left.\beta_{11 i}=0\right)$ & $\Delta \mathrm{LERVOL} \rightarrow \Delta \mathrm{RYG}$ & $\left(\right.$ all $\left.\beta_{11 i}=0\right)$ \\
\hline Chi-square & 0.0851 & Chi-square & $8.2809 * *$ \\
\hline Ho: $\Delta$ LM1 $\rightarrow \Delta$ LERVOL & $\left(\right.$ all $\left.\beta_{31 i}=0\right)$ & $\Delta \mathrm{LERVOL} \rightarrow \Delta \mathrm{LM} 1$ & $\left(\right.$ all $\left.\left.\beta_{31 i}=0\right)\right)$ \\
\hline Chi-square & 1.2157 & Chi-square & $6.7964 * *$ \\
\hline Ho: $\Delta$ LIBR $\rightarrow \Delta$ LERVOL & $\left(\right.$ all $\left.\beta_{41 i}=0\right)$ & Ho: $\triangle \mathrm{LERVOL} \rightarrow \Delta \mathrm{LIBR}$ & $\left(\right.$ all $\left.\beta_{41 i}=0\right)$ \\
\hline Chi-square & $64.0442 * * *$ & Chi-square & 0.2028 \\
\hline Ho: $\Delta$ LCPI $\rightarrow \Delta$ LERVOL & $\left(\right.$ all $\left.\beta_{21 i}=0\right)$ & Ho: $\Delta$ LERVOL $\rightarrow \Delta$ LCPI & $\left(\right.$ all $\left.\beta_{21 i}=0\right)$ \\
\hline Chi-square & 4.3398 & Chi-square & 0.7724 \\
\hline
\end{tabular}

Note. $*$, **, and $* * *$ denote levels of significance at $10 \%, 5 \%$, and $1 \%$, respectively.

\subsection{Impulse-Response Function (IRF)}

Impulse-response function allows for a graphical observation of the reaction of a dynamic system to some input signal or external shock. It depicts the system's response as a function of some explanatory parameters that represent the system's dynamic behavior. Our IRF investigated the effect of Cholesky one standard deviation innovation on the behavior of the time series. As shown in Figure 3, growth's impulse response to a one SD of CPI is positive while to that of the money supply is initially negative, although it starts to become positive around the third month with a sign of possible convergence. IBR was negative albeit insignificant with no immediate sign of convergence. The response of growth to interest rate (PLR) was also negative - an intuitive outcome-implying that a positive shock to PLR (increase) would cause growth to decline. The effect of ERVOL on growth was outright negative, an a priori outcome, testifying to the adverse effects of exchange-rate instability on economic growth.
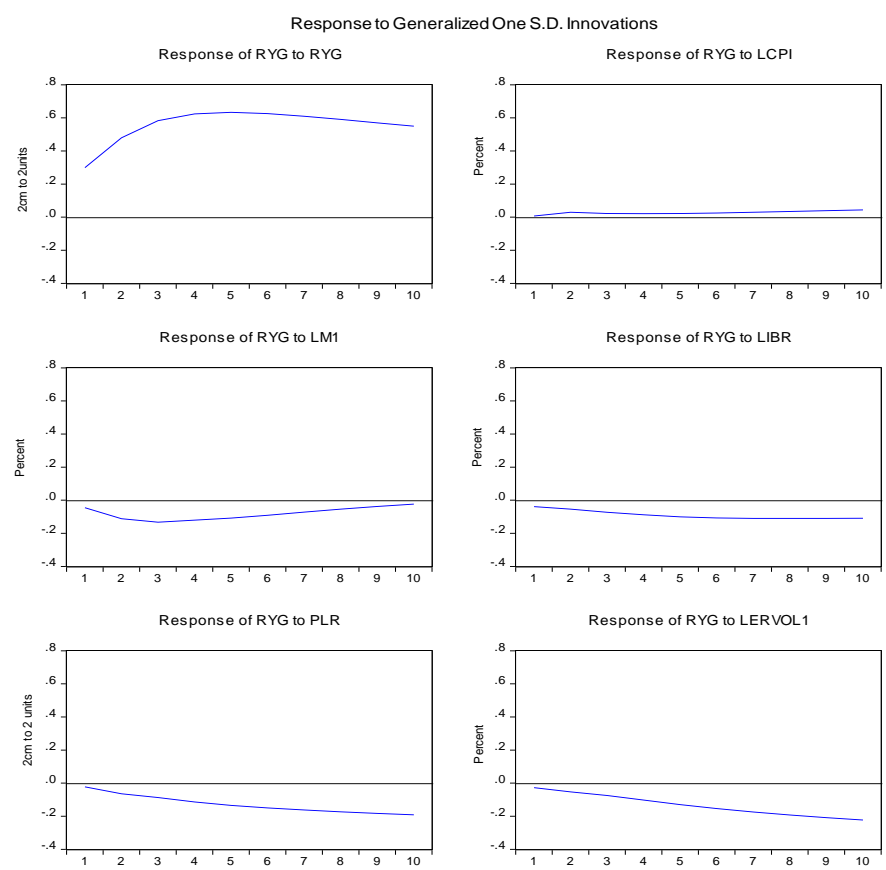

Figure 3. Generalized Impulse-Response Functions (IRFs) of RYG, LCPI, LM1, LIBR, PLR and LERVOL to Cholesky One S.D. Innovation 


\subsection{VECM Diagnostic Tests}

The VEC residual correlation LM test indicated no serial correlation in our model residuals. Similarly, the VEC residual portmanteau test also showed no sign of autocorrelation. However, the model showed the presence of heteroscedasticity.

\section{Conclusion and Policy Implications}

This study used a vector error correction model and dynamic causal linkages (DCLs) to check for the influence of interbank exchange rate, prime lending rate, consumer price index, and bilateral USD/NGA movements on Nigeria's economic growth. The model utilized monthly data from 2003 to 2017. The VECM results, as seen in the impulse-response functions, indicated that USD/NGN volatility had a negative effect on the country's GDP growth. This outcome was also confirmed by the Granger causality/block exogeneity Wald tests. Furthermore, the results showed that USD/NGN exchange-rate volatility exhibited short-term unidirectional causality on economic growth. A bidirectional relationship was also confirmed between narrow money supply and economic growth. However, it was also found that the interbank exchange rate, which is a semiofficial Forex window, had little effect on Nigeria's economic growth - a strong indication that a large portion of the productive sector lacks access to this Forex platform. These findings imply that exchange-rate volatility does not augur well for growth in Nigeria at least in the short term. Furthermore, a more succinct impulse-response analysis showed a long-term negative influence on economic growth, and while the money supply first showed a negative influence, it later turned positive - essentially, an a priori expectation regarding the money supply-economic growth relationship, at least in the short term. No signs of autocorrelation were detected in the model. However, the findings of the study are limited to the scope of the data.

\section{Disclaimer}

This article should not be reported as representing the views of the CBN. The views expressed herein are those of the author(s) and are not necessarily those of the Central Bank of Nigeria and its Management

\section{References}

Adelowokan, A. A., Adesoye, A. B., \& Balogun, O. D. (2015). Exchange Rate Volatility on Investment and Growth in Nigeria, an Empirical Analysis. Global Journal of Management and Business Research: B Economics and Commerce, 15(10).

Adeoye, B. W., \& Atanda, A. A. (2012). Exchange rate volatility in Nigeria: Consistency, Persistency and severity analyses. CBN Journal of Applied Statistics, 2(2), 29-49.

Aghion, P., Bacchetta, P., Rancière, R., \& Rogoff, K. S. (2009). Exchange Rate Volatility and Productivity Growth: The Role of Financial Development. Journal of Monetary Economics, 56, 494-513. https://doi.org/10.1016/j.jmoneco.2009.03.015

Ajakaiye, D. O., \& Ojowu, O. (1994). Exchange Rate depreciation and the Structure of Sectoral Prices in Nigeria under an alternative pricing regime, 1986-89. NISER Publication, Research Paper No. 25.

Alagidede, P. C., \& Ibrahim, M. (2016). On the causes and effects of exchange rate volatility on economic growth: Evidence from Ghana. International Growth Centre, Working Paper, 1994, 1-27.

An, L., \& Sun, W. (2008). Monetary Policy, Foreign Exchange Intervention, and the Exchange Rate: The Case of Japan. International Research Journal of Finance and Economics, 15.

Anderson, G., \& Kavajecz, K. A. (1994). A historical perspective on the Federal Reserve's monetary aggregates: Definition, construction and targeting. Federal Bank of St. Louis Review, 76, 1-31. https://doi.org/10.20955/r.76.1-31

Ang, J. B., \& McKibbin, W. J. (2007). Financial liberalization, financial sector development andGrowth: Evidence from Malaysia. Journal of Development Economics, 215-233. https://doi.org/10.1016/j.jdeveco.2006.11.006

Arize, A. C., Osang, T., \& Slottje, D. J. (2000), Exchange-rate volatility and foreign trade: evidence from thirteen LDCs. Journal of Business \& Economic Statistics, 18(1), 10-17. https://doi.org/10.1080/07350015.2000.10524843

Bahmani-Oskooee, M. (1998). Are Devaluations Contractionary? Journal of Economic Development, 23(1), 131-43.

Bahmani-Oskooee, M., \& Miteza, I. (2006). Are Devaluations Contractionary? Evidence from Panel Cointegration. Economic Issues, 11(1), 49-64. 
Barguellil, A., Ben-Salha, O., \& Zmami, M. (2018). Exchange rate volatility and economic growth. Journal of Economic Integration, 33(2), 1302-1336. https://doi.org/10.11130/jei.2018.33.2.1302

Berg, A., \& Miao, Y. (2010). The Real Exchange Rate and Growth Revisited: The Washington Consensus Strikes Back? IMF Working Paper, 10/58. https://doi.org/10.5089/9781451963755.001

Berument, H., \& Pasaogullari, M. (2003). Effects of the Real Exchange Rate on Output and Inflation: Evidence from Turkey. The Developing Economies, 41(4), 401-435. https://doi.org/10.1111/j.1746-1049.2003.tb01009.x

Bhadury, S. S. (2016). Bringing 'Money' Back in Monetary Models of Exchange Rate. PhD Dissertation (unpublished) submitted to the graduate degree program in the Department of Economics and the Graduate Faculty of the University of Kansas.

Bjornland, H. (2009). Monetary Policy and Exchange Rate Overshooting: Dornbusch was right after all. Journal of International Economics, 79, 64-77. https://doi.org/10.1016/j.jinteco.2009.06.003

Bollerslev, T. (1986). Generalized AutoRegressive Conditional Heteroskedacticity. Journal of Econometrics, 31(3), 307-327. https://doi.org/10.1016/0304-4076(86)90063-1

Bruggeman, A., Camba-Mendez, G., Fischer, B., \& Sousa, J. (2005). Structural Filters for Monetary Analysis: the Inflationary Movements of Money in the Euro Area. ECB Working Paper, No. 470.

Chowdury, T. (2005). Exchange Rate Volatility and the United States Exports: Evidence from Canada and Japan. Journal of Japanese and International Economics, 19, 51-71. https://doi.org/10.1016/j.jjie.2003.11.002

Christiano, L. J., Motto, R., \& Rostagno, M. (2007). Two Reasons Why Money and Credit May Be Useful in Monetary Policy. NBER Working Paper, N0. 13502. https://doi.org/10.3386/w13502

Clarida, R., \& Gali, J. (1994). Sources of Real Exchange Rate Fluctuations: How Important are Nominal Shocks? Carnegie Rochester Series on Public Policy, 41(1), 1-56. https://doi.org/10.1016/0167-2231(94)00012-3

Cochrane, J. H. (2007). Inflation Determination with Taylor Rules: a Critical Review. NBER Working Paper, $n$. 13409. https://doi.org/10.2139/ssrn.1012165

Connolly, M. (1983). Exchange Rates, Real Economic Activity and the Balance of Payments: Evidence from the 1960s. In E. Classesn, \& P. Salin (Eds.), Recent Issues in the Theory of Flexible Exchange Rates. Amsterdam: North Holland.

Danmola, R. A. (2013). The Impact of Exchange Rate Volatility on the Macro Economic Variables in Nigeria. European Scientific Journal, 9(7).

DeJong, D., Nankervis, J., Savin, N., \& Whiteman, C. (1992). Integration versus Trend Stationary in Time Series. IMF Staff Papers, 63-84. https://doi.org/10.2307/2951602

Devereux, M. B., \& Lane, P. R. (2003). Understanding Bilateral Exchange Rate Volatility. Journal of International Economics, 60(1), 109-132. https://doi.org/10.1016/S0022-1996(02)00061-2

Diaz-Alejandro, C. (1963). A note on the impact of devaluation and the redistributive effect. Journal of Political Economy, 71, 577-80. https://doi.org/10.1086/258816

Dollar, D. (1992). Outward-Oriented Developing Economies Really Do Grow More Rapidly: Evidence from 95 LDCs, 1976-1985. Economic Development and Cultural Change, 40(3), 523-544. https://doi.org/10.1086/451959

Dornbusch, R. (1976), Expectations and Exchange Rate Dynamics. Journal of Political Economy, 84, 1161-1176. https://doi.org/10.1086/260506

Easterly, W. (2005). National Policies and Economic Growth: A Reappraisal. In A. Philippe, \& S. Durlauf (Eds.), Handbook of Economic Growth (Volume 1A). Elsevier. https://doi.org/10.1016/S1574-0684(05)01015-4

Ebuh, G. U., Ezike, I. B., Shitile, T. S., Smith, E. S., \& Haruna, T. M. (2019). The Infrastructure-Growth Nexus in Nigeria: A Reassessment. Journal of Infrastructure Development, 1-18. https://doi.org/10.1177/0974930619872096

Edwards, S. (1986). Are Devaluations Contractionary? Review of Economics and Statistics, 501-508. https://doi.org/10.2307/1926028

Eichenbaum, M., \& Evans, C. L. (1995). Some Empirical Evidence on the Effects of shocks to Monetary Policy on Exchange Rate. The Quarterly Journal of Economics, 110(4), 975-1009. https://doi.org/10.2307/2946646 
Elliot, G., Rothenberg, T., \& Stock, J. (1996). Efficient Test for for an Autoregressive Unit Root. Econometrica, 64, 813-836. https://doi.org/10.2307/2171846

El-Ramly, H., \& Abdel-Haleim. (2008). The Effect of Devaluation on Output in the Egyptian Economy: A Vector Autoregression Analysis. International Research Journal of Finance and Economics, 14.

Emerah, A. A., Adeleke, E., \& David, J. O. (2015). Exchange Rate Volatility and Economic Growth in Nigeria (1986-2013). Journal of Empirical Economics, Research Academy of Social Sciences, 4(2), 109-115.

Eneji, M. A., Nanwul, D. F., Eneji, A. I., Anga, R., \& Dickson, V. (2018). Effect of Exchange Rate Policy and its Volatility on Economic Growth in Nigeria. International Journal of Advanced Studies in Economics and Public Sector Management, 6(2), 166-190.

Engle, R. F., \& Granger, C. W. J. (1987). Co-integration and Error Correction: Representation, Estimation and Testing. Econometrica, 55, 251-276. https://doi.org/10.2307/1913236

Esteve, V., \& Tamarit, C. (2012). Threshold Cointegration and Nonlinear Adjustment Between CO2 and Income: The Environmental Kuznets Curve in Spain, 1857-2007. Energy Economics, 34, 2148-2156. https://doi.org/10.1016/j.eneco.2012.03.001

Faust, J., \& Rogers, J. H. (2003). Monetary policy's role in exchange rate behaviour. Journal of Monetary Economics, 50, 1403-1424. https://doi.org/10.1016/j.jmoneco.2003.08.003

Favero, C. A., \& Marcellino, M. (2005). Modelling and Forecasting Fiscal Variables for the Euro Area. Oxford Bulletin of Economics and Statistics, 1, 755-783. https://doi.org/10.1111/j.1468-0084.2005.00140.x

Fourie, J., Pretorious, T., Harvey, R., \& Van Niekerk, H. P. (2016). Nonlinear Relationship Between Exchange Rate Volatility and Economic Growth: A South African Perspective. MPRA Paper \#: 74671.

Frankel, J., \& Rose, K. A. (2002). A Contribution to the Theory of Economic Growth. The Quarterly Journal of Economics, 117, 437-466. https://doi.org/10.1162/003355302753650292

Gauthier, C., \& Tessier, D. (2002). Supply Shocks and Real Exchange Rate Dynamics: Canadian Evidence. Bank of Canada Working Paper No. 2002-31.

Gluzmann, P. A., Levy-Yeyati, E., \& Sturzenegger (2012). Exchange Rate Undervaluation and Economic Growth: Diaz Alejandro (1965) Revisited. Economics Letters, 117, 666-672. https://doi.org/10.1016/j.econlet.2012.07.022

Gylfason, T., \& Radetzki, M. (1985). Does Devaluation Make Sense in the Least Developed Countries? IIES Seminar Paper, University of Stockholm.

Gylfason, T., \& Schmid, M. (1983). Does Devaluation Cause Stagflation? Canadian Journal of Economics, 641-54. https://doi.org/10.2307/135045

Hausmann, R., Panizza, U., \& Rigobon, R. (2006). The Long-Run Volatility Puzzle of the Real Exchange Rate. Journal of International Money and Finance, 25(1), 93-124. https://doi.org/10.1016/j.jimonfin.2005.10.006

Ireland, P. (2001a). Sticky-Price Models of the Business Cycle - Specification and Stability. Journal of Monetary Economics, 47, 3-18. https://doi.org/10.1016/S0304-3932(00)00047-7

Ireland, P. (2001b). Money's Role in the Monetary Business Cycle. Working Paper 8115, National Bureau of Economic Research. https://doi.org/10.3386/w8115

Iyeli, I. (2017). Exchange Rate Volatility and Economic Growth in Nigeria. International Journal of Economics, Commerce and Management, 5(7), 583-595.

Johansen, S. (1988). Statistical Analysis of Cointegrating Vectors. Journal of Economic Dynamics and Control, 12, 231-254. https://doi.org/10.1016/0165-1889(88)90041-3

Kamin, S. B., \& Klau, M. (1998). Some Multi-country Evidence on the Effect of Real Exchange Rate on Output. International Finance Discussion Papers 611, no. 554, Board of Governors of the Federal Reserve System, Washington, D.C. https://doi.org/10.17016/IFDP.1998.611

Kaminsky, G., \& Lewis, K. (1996), Does Foreign Exchange Intervention Signal Future Monetary Policy? Journal of Monetary Economics, 37(2), 285-312. https://doi.org/10.1016/S0304-3932(96)90038-0

Katusiime, L., Agbola, F. W., \& Shansuddin, A. (2015). Exchange rate volatility-economic growth nexus in Uganda. Applied Economics, 48(26), 1-15. https://doi.org/10.1080/00036846.2015.1122732

Khan, M. K., Teng, J. Z., \& Khan, M. I. (2019). Cointegration between Macroeconomic Factors and the 
Exchange Rate USD/CNY. Financial Innovation, 5(5), 1-15. https://doi.org/10.1186/s40854-018-0117-x

Khosa, J., Botha, I., \& Pretorius, M. (2015). The Impact of Exchange Rate Volatility on Emerging Market Exports. Acta Commercii, 15(1), 1-11. https://doi.org/10.4102/ac.v15i1.257

Kim, C. B. (2017). Does Exchange Rate Volatility Affect Korea's Seaborne Import Volume? The Asian Journal of Shipping and Logistics, 33(1), 043-050. https://doi.org/10.1016/j.ajsl.2017.03.006

Kim, S., \& Roubini, N. (2000). Exchange Rate Anomalies in the Industrial Countries: A Solution with a Structural VAR Approach. Journal of Monetary Economics, 45(3), 561-586. https://doi.org/10.1016/S0304-3932(00)00010-6

Kondker, B. H., Bidisha, S. H., \& Razzaque, M. A. (2012). The Exchange rate and Economic Growth: An empirical assessment on Bangladesh. International Growth Centre Working Paper.

Lawal, A. I., Atunde, I. O., Ahmed, V., \& Asaleye, A. (2016). Exchange Rate Fluctuation and the Nigeria Economic Growth. EuroEconomica, 35(2).

Lewis, K. (1995), Are Foreign Exchange Intervention and Monetary Policy Related and Does it Really Matter? Journal of Business, 68(2), 185-214. https://doi.org/10.1086/296660

Lizondo, J. S., \& Montiel, P. (1989). Contractionary devaluation in developing countries: An analytical overview. IMF Staff Papers, 36. https://doi.org/10.2307/3867174

MacDonald, R., \& Nagayasu, J. (1999). The Long-Run Relationship Between Real Exchange Rates and Real Interest Rate Differentials: A Panel Study. IMF Working Paper No. 99/ 37. http://dx.doi.org/10.5089/9781451845556.001

Masuch, K. S., Nicoletti-Altimari, S., \& Rostagno, M. S. (2003). The role of money in monetary policy making. BIS Working Paper, n 19-2003. https://doi.org/10.2139/ssrn.517702

Mbaye, S. (2012). Real Exchange Rate Undervaluation and Growth: Is there a Total Factor Productivity Growth Channel? CERDI, Etudes et Documents, E 2012.11.

Mpofu, T. (2016). The Determinants of Exchange Rate Volatility in South Africa. ERSA Working Paper, 604. Cape Town: Economic Research Southern Africa.

Musyoki, D., Pokhariyal, G., \& Pundo, M. (2012). Imapct of Exchange Rate Volatility on Economic Growth: Kenya Evidence. Business and Economic Horizons (BEH), 7(1), 59-75. https://doi.org/10.15208/beh.2012.5

Nelson, E. (2003). The future of monetary aggregates in monetary policy analysis. Journal of Monetary Economics, 50(5), 1029-1059. https://doi.org/10.1016/S0304-3932(03)00063-1

Ng, S., \& Perron, P. (2001). Lag Lenght Selection and the Construction of Unit Root Tests with Good Size and Power. Econometrica, 69, 1519-1554. https://doi.org/10.1111/1468-0262.00256

Nnanna, O. J. (2002). Monetary Policy and Exchange Rate Stability in Nigeria. Nigerian Economic Society Proceedings of a One-day Seminar on Monetary Policy and Exchange rate Stability, Federal Palace Hotel, Lagos.

Nsofor, E. S., Takon, S. M., \& Ugwuegbe, S. U. (2017). Modeling Exchange Rate Volatility and Economic Growth in Nigeria. Noble International Journal of Economics and Financial Research, 2(6), 88-97.

Obeng, C. K. (2017). Effects of Exchange Rate Volatility on Non-Traditional Exports in Ghana. Munich: MPRA Paper 79026, University Library of Munich, Germany.

Odusola, A. F., \& Akinlo, A. E. (2001). Output, Inflation and Exchange Rate in Developing Countries: An Application to Nigeria. The Development Economics, 39, 199-222. https://doi.org/10.1111/j.1746-1049.2001.tb00900.x

Oloyede, J. O., \& Fatepu, O. (2018). Effect of Exchange Rate Volatility on Economic Growth in Nigeria (1986-2014). Paper presented at the 9th Economics \& Finance Conference, London, 22 May 2018. https://doi.org/10.20472/EFC.2018.009.011

Owolabi, U. A., \& Adegbite, T. A. (2013). Effect of Exchange Rate Volatility on Nigeria Economy (1991-2010). International Journal of Academic Research in Economics and Management Sciences, 2(6).

Peersman, G., \& Smets, F. (2003). The monetary transmission mechanism in the euro area: more evidence from VAR analysis. In I. Angeloni, A. Kashyap, \& B. Mojon (Eds.), Monetary Policy Transmission in the Euro Area (Part 1, pp. 36-55). Cambridge University Press. https://doi.org/10.1017/CBO9780511492372.004

Perron, P., \& Ng, S. (1996). Useful Modifications to Some Unit Root Tests with Dependent Errors and their 
Local Asymptotic Properties. The Review of Economic Studies, 63, 435-463. https://doi.org/10.2307/2297890

Phiri, A. (2018). Nonlinear Relationship between Exchange Rate Volatility and Economic Growth. Journal of Economics and Econometrics, Economics and Econometrics Society, 61(3), 15-38.

Razzaque, M. A., Bidisha, S. H., \& Khondker, B. H. (2017). Exchange Rate and Economic Growth: An Empirical Assessment for Bangladesh. Journal of South Asian Development, 12(1), $42-64$. https://doi.org/10.1177/0973174117702712

Rhodd, R. (1993). The effects of real exchange rate changes on output: Jamaica's devaluation experience. Journal of International Development, 5, 291-303. https://doi.org/10.1002/jid.3380050305

Rodrik, D. (2008). The Real Exchange Rate and Economic Growth. Brookings Papers on Economic Activity, Fall 2008. https://doi.org/10.1353/eca.0.0020

Rose, A. K. (2000). One Money, One Market: Estimating the Effect of Common Currencies on Trade. Economic Policy, 15(30), 7-45. https://doi.org/10.1111/1468-0327.00056

Rotemberg, J., \& Woodford, J. M. (1999). Interest Rate Rules in an Estimated Sticky Price Model in Monetary Policy Rules (Ed. By J. B. Taylor, pp. 57-119). https://doi.org/10.3386/w6618

Serenis, D., \& Tsounis, N. (2015). Exchange Rate Volatility and Foreign Trade: The Case of Cyprus and Croatia. Procedia Economics and Finance, 5, 677-685. https://doi.org/10.1016/S2212-5671(13)00079-8

Sharifi-Renani, H., Raki, M., \& Honarvar, N. (2014). Monetary policy and exchange rate overshooting in Iran: A Vector Errors Correction (VEC) approach. International Economics Studies, 44(1), 67-74.

Sims, A. C. (1980). Macroeconomics and Reality. Econometrica, 48(1), 1-48. https://doi.org/10.2307/1912017

Takandesa, P., Tsheole, T., \& Azaikpono, M. (2006). Real Exchange Rate Volatility and its Effect on Trade Flows: New Evidence from South Africa. Journal for Studies in Economics and Econometrics, 30, 79-97.

Taylor, J. B. (1993). Discretion versus policy rules in practice. Carnegie Rochester Conference Series on Public Policy, 39(1), 195-214. https://doi.org/10.1016/0167-2231(93)90009-L

Tule, M. K., Odonye, O. J., Afangideh, U. J., Ebuh, G. U., Udoh, E. A. P., \& Ujunwa, A. (2020). Assessing the Spillover Effects of U.S. Monetary Policy Normalization on Nigeria Sovereign Bond Yield. Financial Innovation, 5(32), 1-16. https://doi.org/10.1186/s40854-019-0148-y

Upadhyaya, K., \& Upadhyay, M. (1999). Output effects of devaluation: Evidence from Asia. Journal of Development Studies, 35, 89-103. https://doi.org/10.1080/00220389908422603

VanWijnbergen, S.(1989). Exchange rate management and stabilization policies in developing countries. Journal of Development Economics, 23, 227-47. https://doi.org/10.1016/0304-3878(86)90117-3

Velasco, A. (1999). A Model of Endogenous Fiscal Deficits and Delayed Fiscal Reforms. In J. Poterba, \& J. Von Hagen (Eds.), Fiscal Institutions and Economic Performance. Chicago: University of Chicago Press (NBER).

Yakub, M. U., Sani, Z., Obiezue, T. O., \& Aliyu, V. O. (2019). Empirical Investigation on Exchange Rate Volatility and Trade Flows in Nigeria. Economic and Financial Review, 57(1), 23-46.

\section{Appendix}

Table A1. VEC residual Portmanteau tests for autocorrelations

\begin{tabular}{|c|c|c|c|c|c|}
\hline Lags & Q-Stat & Prob. & Adj. Q-Stat & Prob. & Df \\
\hline 1 & 2.396253 & $\mathrm{NA}^{*}$ & 2.410349 & $\mathrm{NA}^{*}$ & $\mathrm{NA}^{*}$ \\
\hline 2 & 15.71293 & NA* & 15.88462 & $\mathrm{NA}^{*}$ & $\mathrm{NA}^{*}$ \\
\hline 3 & 59.64866 & 0.6960 & 60.60491 & 0.6644 & 66 \\
\hline 4 & 103.6381 & 0.4362 & 105.6479 & 0.3825 & 102 \\
\hline 5 & 131.8112 & 0.6323 & 134.6697 & 0.5643 & 138 \\
\hline 6 & 168.5704 & 0.6019 & 172.7656 & 0.5122 & 174 \\
\hline 7 & 192.3168 & 0.8039 & 197.5256 & 0.7219 & 210 \\
\hline 8 & 210.8277 & 0.9493 & 216.9450 & 0.9091 & 246 \\
\hline 9 & 243.5665 & 0.9525 & 251.5026 & 0.9041 & 282 \\
\hline 10 & 290.0939 & 0.8674 & 300.9198 & 0.7464 & 318 \\
\hline
\end{tabular}

Note. * the test is valid only for lags larger than the VAR lag order; df is degrees of freedom for (approximate) chi-squared distribution. 
Table A2. VEC residual serial correlation LM tests

\begin{tabular}{cll}
\hline Lags & LM-Stat & Prob \\
\hline 1 & 47.77876 & 0.0960 \\
2 & 45.06150 & 0.1019 \\
3 & 44.80371 & 0.1160 \\
4 & 47.26357 & 0.0991 \\
5 & 28.19800 & 0.8201 \\
6 & 37.28989 & 0.4096 \\
7 & 24.09942 & 0.9351 \\
8 & 18.43067 & 0.9933 \\
9 & 32.77758 & 0.6227 \\
10 & 47.92102 & 0.0884 \\
\hline
\end{tabular}

Note. Probs from chi-square with $36 \mathrm{df}$.

\section{Copyrights}

Copyright for this article is retained by the author(s), with first publication rights granted to the journal.

This is an open-access article distributed under the terms and conditions of the Creative Commons Attribution license (http://creativecommons.org/licenses/by/4.0/). 